https://doi.org/10.19195/0137-1134.127.6

\author{
MICHAŁ NAJMAN \\ ORCID: 0000-0001-8207-8458 \\ Uniwersytet Łódzki
}

\title{
JAK ROZUMIEĆ GODNOŚĆ W PRAWIE
}

\begin{abstract}
Abstrakt: W obecnym dyskursie prawniczym pojęcie godności staje się coraz bardziej powszechne. Jest ona uważana za najwyższy aksjomat, którego jakiekolwiek naruszenie zasługuje na naganę. Zapominamy jednak o podstawach koncepcyjnych danego pojęcia, jego historii i etymologii. Nie pamiętamy, że niektóre pojęcia abstrakcyjne powstają wyłącznie w celu usystematyzowania powstałych lub istniejących sytuacji społecznych i politycznych. Celem artykułu jest próba odpowiedzi na pytanie, jak rozumieć pojęcie godności w dyskursie prawnym. Warto pamiętać, że godność jest wskazywana jako „to” (wartość, a może coś innego), z czego wywodzą się prawa człowieka. Postulować należy odrzucenie pojmowania godności jako wartości, ponieważ konstytuuje ona wartości, jednocześnie nią nie będąc. Jeśli chcemy traktować ją jako kategorię prawną, to należy opowiedzieć się za obiektywnym rozumieniem godności, wyłączającym jej tło moralne zaproponowane między innymi przez doktrynę Kościoła katolickiego.
\end{abstract}

Słowa kluczowe: godność, wartość, kategoria prawna

\section{UWAGI WSTĘPNE — GODNOŚĆ A POJĘCIE GODNOŚCI}

Na początek warto zwrócić uwagę na używane zamiennie zwroty „godność” i ,pojęcie godności”. Nie jest to, jak mogłoby się wydawać, błąd przesunięcia kategorialnego przy przyjmowanym rozumieniu pojęć abstrakcyjnych, do których należy zaliczyć godność. Dla jasności wywodu przyjąć należy, że pojęciami abstrakcyjnymi są pojęcia nieposiadające (współcześnie lub w przeszłości) rzeczywiście istniejącego desygnatu (Bóg, honor, ojczyzna, godność, kasta, prawo, Zeus itp.). Nadto należy zwrócić uwagę, że funkcja kreacyjna języka odgrywa wiele ról społecznych, odpowiadając na przykład za funkcję poznawczą, polityczną czy prawną. Oznacza to tyle, że stworzenie danego pojęcia służy ułatwieniu opisania i rozumienia rzeczywistości wyłącznie za pomocą stworzenia nowego pojęcia. Choć współcześnie takie wykorzystanie funkcji kreacyjnej języka jest mniej widoczne w dyskursie publicznym (słusznie zarezerwowane zostało na potrzeby kultury i sztuki), to wciąż jest ono obecne i stanowi zagrożenie dla rozwoju społecznego poprzez wyjaśnianie zjawisk jedynie pojęciem (zwrotem językowym), 
zamiast podejmowania prób wyjaśnienia go empirycznie. Co gorsza, na podstawie tak powstałego pojęcia powstają rozrastające się dziedziny pseudonauki. Niemniej jednak w naukach społecznych i humanistycznych, wliczając w to prawo, nie sposób zrezygnować z tworzenia pojęć abstrakcyjnych (w tym pojęć prawnych) dla zagwarantowania pewności prawa w państwach demokratycznych. Konstytuuje to następujący wniosek: pojęcie abstrakcyjne, jakim jest godność, powinno służyć wyjaśnieniu rzeczywistości (przede wszystkim prawnej), pomimo istnienia wielu pozycji, w których godność (nie pojęcie godności) traktowana jest jako wartość. Przez długotrwałe powielanie takiego wartościowego rozumienia pojęcia godności wielu autorów skupia się na nieistotnych problemach, między innymi czy godność jest wartością najwyższą, czy wartości społeczne (grupowe/kolektywne) są od niej ważniejsze, czy należy ją chronić prawnie. Co więcej, stan zastoju naukowego powoduje, że podważanie utrwalonych znaczeń danych pojęć czy zmiana przyjmowanych założeń przy wyjaśnianiu pewnych zjawisk skutkuje obstrukcją umysłową i ab initio negacją proponowanych rozwiązań. Bo przecież, jak można mówić, że Bóg, honor czy ojczyzna to tylko pojęcia, na których zbudowano filozofię i wiele (nacjonalistycznych i totalitarnych) ustrojów społecznych? Odrzucenie rozumienia godności jako czegoś więcej niż tylko pojęcie i przyjęcie rozwiązania proponowanego przez autora pod koniec wywodu pozwala na uznanie pojęcia godności za kategorię prawną prawidłowo usytuowaną w systemie prawnym.

\section{WPROWADZENIE}

Godność stanowi metapojęcie uzasadniające istnienie innych pojęć, na przykład dobrego imienia. Współcześnie większość instytucji społecznych ${ }^{1}$ nie posiada realnie istniejących desygnatów. Ciężar dyskursu przeniesiony został w sferę językową reprezentującą pewne wrażenia emocjonalne, które łączymy z danymi pojęciami. Zachodzi tu prosty proces tworzenia relacji syntagmatycznej ${ }^{2}$. Często jednak przedsięwzięcie to jest niewystarczające i następuje po nim odwrotny proces (relacja paradygmatyczna), to znaczy znaczenie zjawiska opisywanego pojęciem abstrakcyjnym uzasadniane jest przez sądy wykorzystujące inne pojęcie abstrakcyjne ${ }^{3}$. Taka relacja niewątpliwie istnieje między czcią i godnością. Określenie jej etymologii i ewolucji znaczenia jest niełatwe, jednak warto podjąć

1 D. North, Institutions, Institutional Change and Economic Perfomance, New York 1990, s. 2.

2 R. Bartsch, Dynamic Conceptual Semantics. A Logico-Philosophical Investigation into Concept Formation and Understanding, Leyland 1998, s. 78.

3 Jak wskazano powyżej, chodzi tu o funkcję poznawczą pojęć abstrakcyjnych. Typowym przykładem wyjaśniania zjawiska opisanego pojęciem abstrakcyjnym za pomocą innego sądu opisanego pojęciem abstrakcyjnym są mitologie. 
się tego wysiłku, gdyż etymologia wyjaśnia istotę pojęcia ${ }^{4}$. Na początku trzeba jednak zaznaczyć, że pierwsze koncepcje godności w zasadzie jej nie definiują, a jedynie wyjaśniają jej genezę uzasadniającą szczególną rolę człowieka w świecie $^{5}$. Część autorów w godności widziała istotę człowieka, jego cel istnienia 6 . Kolejno pojęcie to ulegało ewolucji w stronę tego, co wynika dla człowieka z jej posiadania (imperatywizacja godności ${ }^{7}$ ). Część twórców w ogóle nie poruszała tematu godności samej w sobie, jednak ze względu na jej współcześnie rozumianą intensję przypisuje się ich rozumowaniom odniesienie do pojęcia godności ${ }^{8}$. Najistotniejszą kwestią wydaje się tutaj jednak charakter logiczny pojęcia godności i jej funkcja wyjaśniająca inne pojęcia (zjawiska), z czego powstają zarysowane problemy interpretacyjne. $Z$ tej właśnie funkcji wynika rozbieżność w jej rozumieniu. Jedni określali za jej pomocą szczególną pozycję człowieka w świecie lub społeczeństwie, inni odczytywali ją jako uzasadnienie etycznego postępowania, jeszcze inni jako podstawę istnienia praw (człowieka). Nadto nie można też mówić o linearnym rozwoju koncepcji godności. Koncepcje aktualne współcześnie znane były już od lat najdawniejszych ${ }^{9}$ (na przykład równość wszystkich ludzi w filozofii Protagorasa $^{10}$ i Seneki ${ }^{11}$ ), lecz jako niewpisujące się w rozumienie właściwe dla danej epoki często pomijane są w rozważaniach. Innym błędem w rozumieniu pojęcia godności jest przypisywanie sztywności jego (subiektywnie rozumianej) intensji i na tej podstawie przypisywanie autorom koncepcji godności ${ }^{12}$, mimo że nie było nawet ich celem stworzenie takiego dzieła ${ }^{13}$.

\section{ANALIZA LINGWISTYCZNA POJĘCIA GODNOŚCI}

Pojęcie godności pochodzi od staropolskiego god, oznaczającego czas. Od czego współczesne gody, godzina, dogodny, jak również godny, czyli pierwotnie

${ }^{4}$ Platon, Kratylos, przeł. W. Stefański, Wrocław 1990, s. 23.

5 K. Gilfillan, An Aristotelian Conception of Dignity: Magnanimity and the Happy Life of the Philosopher, Fort Worth, TX 2015, s. 27-31.

6 F.J. Mazurek, Godność osoby ludzkiej podstawa praw człowieka, Lublin 2001, s. 23.

7 W. Tatarkiewicz, Historia filozofii, t. 2, Warszawa 1988, s. 161-184.

8 M. Piechowiak, Tomasza z Akwinu koncepcja godności osoby ludzkiej jako podstawy prawa. Komentarz do rozdziałów 111-113 księgi III Tomasza z Akwinu. Summa contra gentiles, „Poznańskie Studia Teologiczne" 2013, nr 14, s. 221.

9 S. Swieżawski, Dzieje filozofii europejskiej w XV wieku, t. 6. Człowiek, Warszawa 1983, s. 185.

10 A. Verdoss, Statisches und dynamisches Naturrecht, Freiburg 1971, s. 86.

11 F.J., Mazurek, Godność..., s. 21-22.

12 E. Soto Kloss, Starotestamentowe podstawy godności człowieka, [w:] Godność jako kategoria prawna (opracowania i materiaty), red. K. Complak, Wrocław 2001, s. 58-63.

13 A. Krokiewicz, Sokrates. Etyka Demokryta i hedonizm Arystypa, Warszawa 2000, s. 161165. 
na czas, w porę, które z czasem zaczęło wyrażać stosowny, zacny, godziwy, odpowiedni, od czego pochodzą odpowiednie formy rzeczownikowe ${ }^{14}$. Bardzo zbliżona jest geneza łacińskiego dignitas, z protoindoeuropejskiego przedrostka dek-, czyli akceptować, z czego decus, decor (przystojność, uroda, wdzięk) ${ }^{15}$, kolejno łaciński dignus - odpowiedni, pasujący, wartościowy i finalnie: wartość ${ }^{16}$. Podobna jest również etymologia greckiego $\alpha \xi ı \pi \rho \varepsilon ́ \pi \varepsilon 1 \alpha$ pochodzącego od słów $\alpha \xi 10-$ war-

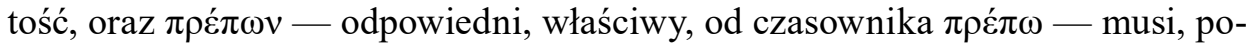

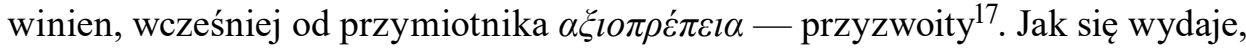
wykazana etymologia słów leży u podstaw interpretowania odprzymiotnikowego rzeczownika godność jako tego, co przystoi, uznawania godności za wyznacznik moralny ${ }^{18}$. Aby rozumieć współczesne, w szczególności normatywne, pojmowanie pojęcia godności, należy zwalczać jego skostniałą wykładnię opierającą się na tym archaicznym znaczeniu. Godność jako właściwość człowieka nie ma nic wspólnego z etyką. Odrzucić należy też zwroty poczucie godności, godność osobowościowa oraz godność osobista, mające podłoże psychologiczno-socjologiczne, to jest uzasadniające takowe zjawiska, a więc skrajnie zsubiektywizowane ${ }^{19}$.

\section{GODNOŚĆ W FILOZOFII STAROŻYTNEJ}

Godność w filozofii starożytnej rozumiana była subiektywistycznie. Pojęcie to opisywało wartość człowieka i uzasadniało jego szczególną pozycję w świecie. Jej podłoże miało charakter zewnętrzny, a jej źródłem był Stwórca (Demiurg) ${ }^{20}$. Wspomnieć jednak należy pogląd Plutarcha o bogach, że ludzie (mędrcy) dorównują im cnotą i szczęściem ${ }^{21}$. Pojęcie to nie było też jednolite treściowo. Często przyznanie człowiekowi przymiotu godności uzależnione było od jego statusu społecznego (mędrzec, arystokrata, obywatel) ${ }^{22}$, płci lub wieku ${ }^{23}$. Traktowana

14 A. Brückner, Słownik etymologiczny języka polskiego, Kraków 1927, s. 147-148.

15 M. Środa, Idea godności w kulturze i etyce, Warszawa 1993, s. 8.

16 Dignity, [hasło w:] Online Etymology Dictionary, https://www.etymonline.com/word/dignity (dostęp: 30.06.2019).

17 https://el.wiktionary.org/wiki/\%CE\%B1\%CE\%BE\%CE\%B9\%CE\%BF\%CF\%80\%CF\%81 \%CE\%B5\%CF\%80\%CE\%AE\%CF\%82 (dostęp 30.06.2019).

18 M. Środa, op. cit., s. $111 \mathrm{n}$.

19 J. Mariański, Godność ludzka jako wartość społeczno-moralna: mit czy rzeczywistość? Studium interdyscyplinarne, Torun 2016, s. 109.

20 M. Piechowiak, Plato and the Universality of Dignity, „Themis Polska Nova” 2015, nr 2, s. $9-10$.

21 Plutarch, Moralia: wybór pism filozoficzno-popularnych, przeł. i oprac. Z. Abramowiczówna, Wrocław 1954, s. 33.

22 M. Środa, op. cit., s. 17-71.

${ }^{23}$ L. Bosek, Gwarancje godności ludzkiej i ich wpływ na polskie prawo cywilne, Warszawa 2012, s. 13. 
była jako cnota. W filozofii starożytnej Grecji (Platon, Arystoteles) była to wartość wtórna w stosunku do człowieka i do jego działania. Dopiero czyny człowieka decydowały o tym, czy posiada on godność ${ }^{24}$. Nawiązując do etapów tworzenia pojęć w aspekcie teleologicznym, pojęcie godności miało uzasadniać istnienie stanów emocjonalnych człowieka (dusza, wola) ${ }^{25}$. Miało to także statuować oderwanie człowieka od wszechświata, brak jego zdeterminowania instynktem, a dokładniej zdolność do panowania nad emocjami. Człowiek był godny, gdy umiał kontrolować swoje emocje ${ }^{26}$.

Godność w filozofii starożytnego Rzymu rozumiana było odmiennie niż w ujęciu Platona i Arystotelesa. W rozumieniu stoików była stanem wewnętrznym człowieka przejawiającym się jako poczucie własnej wartości, przy czym nie była ona przymiotem właściwym jedynie człowiekowi, ale wszelkim przedmiotom i zjawiskom, których ceny nie można było określić, choć niewątpliwe stanowiły one jakąś wartość ${ }^{27}$. Cycero rozumiał godność jako urząd, godny honoru, szacunku i powagi ${ }^{28}$. Uważa się to za pierwsze użycie pojęcia godności ${ }^{29}$, choć takiego określenia na stanowisko państwowe używał już Ksenofont ${ }^{30}$.

W Biblii, szczególnie w Starym Testamencie, wykreowany został portret człowieka jako imago $D e i^{31}$. Egzegeza Pisma Świętego jest klasycznym przykładem błędnego rozumienia pojęcia godności przez przypisywanie mu jej współczesnego rozumienia. Człowiek w Biblii jest zastępcą Boga na Ziemi, a jego istnienie ma koncentrować się na realizacji woli boskiej. Człowiek jest wolny ${ }^{32}$, ale jako stworzenie boskie obdarzone rozumem ma postępować tak, jak nakazał mu Bóg ${ }^{33}$. $Z$ jednej strony godność $\mathrm{w}$ znaczeniu biblijnym (stworzenie na podobieństwo Boga) rozumiana jest jako źródło $\operatorname{praw}^{34}$, $\mathrm{z}$ drugiej — jako wyznacznik postępowania zgodnego z wolą Stwórcy.

${ }^{24}$ M. Jendrzejczak, Idee sprawiedliwości oraz własności w interpretacji Platona i Arystotelesa, „Studia Ekonomiczne. Zeszyty Naukowe Uniwersytetu Ekonomicznego w Katowicach” 2015, nr 236, s. 9-10.

25 J. Domański, Godność człowieka a zagadnienie jego wolności w filozofii starożytnej, [w:] Zagadnienie godności człowieka, red. J. Czerkawski, Lublin 1994, s. 11-13.

26 Plutarch, Moralia..., s. 248-278.

27 Lucius Annaeus Seneca (Seneka), Listy moralne do Lucyliusza, przeł. W. Kornatowski, Warszawa 2010, s. 114.

28 Zob. M.T. Cicero (Cyceron), O inwencji retorycznej/De inventione, przeł. K. Ekies, Warszawa 2013.

29 M. Środa, op. cit., s. 8.

30 Xenophon, Memorabilia, Ithaca-London 1994, s. 86.

31 S. Swieżawski, op. cit., s. 192.

32 P. Duchliński, A. Kobyliński, R. Moń, E. Podrez, Etyka a fenomen życia, Kraków 2017, s. $197-198$.

33 A.N. Woznicki, Dignity of Man as a Person. Essays on the Christian Humanism of His Holiness John Paul II, San Francisco 1987, s. 1-2.

34 A. Maryniarczyk, Dekalog a prawo naturalne, „Człowiek w kulturze. Pismo poświęcone filozofii i kulturze" 1994, nr 3, s. 145-146. 
W filozofii starożytnej godność nie była przyrodzona i niezbywalna, to znaczy, że można było ją utracić. Przysługiwała również tylko części społeczeństwa. Była rozumiana jako cnota, która może być przypisana nielicznym. Cyceron określał cnotę jako sprawność ducha zgodną z regułami zarówno natury, jak i umysłu, która była efektem działania rozumu ${ }^{35}$. Jej pochodzenie miało wobec ludzi charakter zewnętrzny i wtórny. Źródłem godności człowieka byli bogowie, a aktualizowała się ona w czynach. Rozumiana więc była jako norma moralna postępowania jednostki.

\section{GODNOŚĆ W FILOZOFII ŚREDNIOWIECZA}

Filozofia średniowieczna skupiona przede wszystkim na pojęciu Boga niewiele uwagi poświęcała człowiekowi in generale, a jeśli już, to czyniła to przez pryzmat Zbawiciela. Podstawą istnienia godności, podobnie jak w antyku, były czynniki zewnętrze. Rozumiano ją jako aksjomat moralny. Bóg jako doskonałość przejawiał się w człowieku w postaci wolnej woli ${ }^{36}$. Godność przypisać można było temu, kto postępował godnie, czyli cnotliwie. Człowiek miał dążyć do świętości, powrotu do stanu sprzed pierwszego grzechu ${ }^{37}$. Cnoty nie stanowiły części natury ludzkiej ${ }^{38}$, ale można było je udoskonalać, co wymagało wysiłku. I to wkładanie wysiłku w rozwój cnót nazywano godnością ${ }^{39}$. Zdobywanie cnoty odbywało się przez heroizm lub ascezę. Tak więc człowiek formalnie był najdoskonalszym bytem, ale w porównaniu z Bogiem był niedoskonały, a jego celem było dążenie do doskonałości. Św. Augustyn uznawał cnotę za właściwość duszy, która nakłania do czynienia dobra, za pomocą której Bóg oddziałuje na człowieka, a nawet działa w człowieku ${ }^{40}$. Święty Tomasz rozumiał godność jako przymiot istot, które są rozumne i wolne ${ }^{41}$. Jako istotę godności Akwinata wskazywał „dobroć kogoś ze względu na niego samego”, „coś szlachetnie korzystnego i pozytywnego dla kogoś ze względu na niego samego”, „,coś w kimś dla niego dobrego"42. Godność, jak się wydaje, miała być wyjaśnieniem fenomenu myślenia, jak również wolno-

35 M.T. Cicero (Cyceron), O państwie. O prawach. O powinnościach. O cnotach, Warszawa 1960, s. 654.

36 Św. Augustyn, Wyznania, przeł. Z. Kubiak, Kraków 2018, s. 12-26.

37 F. van Steenberghen, R. Guindon: Béatitude de théologie morale chez Saint Thomas d'Aquin - Interpretation, „Revue Philosophique de Louvain” 1959, nr 55, s. 477-478.

38 J.B. Korolec, Perfekcjonizm kultury średniowiecznej, [w:] Zagadnienie godności..., s. 2527.

39 Na krawędzi epoki. Rozwój duchowy i działania człowieka, red. J. Rudniański, K. Murawski, Warszawa 1985, s. 100.

40 J.B. Korolec, op. cit., s. 25-27.

41 S. Pickaers, La dignité de l'homme selon Saint Thomas d'Aquin, [w:] De dignitate hominis, red. A. Holdeeregger, R. Imbach, R. Suárez de Miguel, Freiburg 1987, s. 91.

${ }^{42}$ M. Gigacz, Filozoficzna identyfikacja godności osoby, [w:] Zagadnienie godności..., s. 116. 
ści ${ }^{43}$ (wolnej woli), które pozwalały przezwyciężyć zdeterminowanie instynktów właściwych zwierzętom ${ }^{44}$. Ciekawe poglądy na temat godności zaprezentował w tym okresie również Franciszek Sylwester z Ferrary, zwany Ferrańczykiem. Według niego człowiek jest niedoskonałym obrazem Boga, ale jednocześnie w największym stopniu podobnym do Boga ${ }^{45}$. Sama teleologia pojęcia godności nie odbiega znacząco od poprzedników i służy wyjaśnieniu istnienia rozumu człowieka. Mądrość sprawia, że człowiekowi można przypisać walor godności, lecz jest ona jedynie stopniem doskonałości, a nie elementem strukturalnym bytu. Tak samo jak zróżnicowane są ciała ludzkie, tak samo zróżnicowane są dusze jako ich formy indywidualne. Dlatego istnieje zróżnicowanie co do stopnia szlachetności (nobilitas) wśród ludzi, ale

jeden człowiek nie jest $\mathrm{z}$ tego względu bardziej (magis) człowiekiem od drugiego, chociaż byłby człowiekiem doskonalszym, przeto tego określenia (bardziej) nie używamy inaczej, jak tylko do form, w których zachodzi zmiana między bardziej i mniej, co nie ma miejsca w duszy intelektualnej, ponieważ każdą tę doskonałość, którą na początku otrzyma, zachowuje substancjalnie niezmienną. Może więc być jeden człowiek lepszy od drugiego mocą intelektu, ponieważ ma lepszą i szlachetniejszą duszę, jakkolwiek i to może pochodzić z lepszej dyspozycji władz zmysłowych, której wymaga od nich w swoim działaniu intelekt ${ }^{46}$.

Mądrość jest przyrodzona każdemu człowiekowi i jej poziom nie pozwala określić człowieka inaczej niż człowiekiem, chociażby nie reprezentował on właściwości intelektualnych właściwych przeciętnym przedstawicielom gatunku ludzkiego. Jest to duża innowacyjność w doktrynach średniowiecznych. Poglądy Ferrańczyka w pewien sposób nadają godność także zwierzętom, gdyż istoty nierozumne (zwierzęta) reprezentują Boga na podobieństwo pozostawionego śladu (vestigium ${ }^{47}$. Skutek reprezentuje przyczynę, umożliwiając poznanie sprawczości tej przyczyny, czyli zwierzęta również reprezentują Boga. Co więcej, godność człowieka wynika z tego, że jest on obrazem Boga, ale również z tego, że odzwierciedla on stworzenie w całości. „Natura intelektualna zawiera bowiem wirtualnie wszystkie stopnie formalne innych rzeczy, jak i dusza rozumna zawiera zjednoczo-

43 Św. Tomasz bodajże jako pierwszy dostrzegał zależności między rozumem a wolnością, a przecież wolność wynika z rozumu. Ale czy możliwa jest konwersja tych wartości, to jest stwierdzenie, że myśli tylko ten, kto jest wolny, a rozum właściwy jest tylko istotom wolnym. Zarówno zwierzęta, jak i ludzie, są wolne w tym sensie, że mogą niezależnie od innych podejmować decyzje, są w stanie przewidzieć konsekwencje swoich czynów (pomijając kwestię tego, w jaki sposób środowisko zewnętrzne determinuje zachowania).

${ }^{4}$ M.A. Krąpiec, Człowiek bytem osobowym. Św. Tomasza koncepcja człowieka, [w:] O godność osoby ludzkiej. Materiały Ogólnopolskiej Konferencji Naukowej zorganizowanej przez Stowarzyszenie SPES VITAE, Radom 22-23 marca 2002 r., red. L.J. Kułakowski, U. Antolak-Kułakowska, Radom 2002, 25-27.

45 M. Ciszewski, Godność człowieka i wzniosłość nauki o nim w ujęciu Franciszka Sylwestra z Ferrary, [w:] Zagadnienie godności..., s. 47.

46 Ibidem, s. 56.

47 Ibidem, s. 53. 
ne inne formy $[. .$.$] dlatego, że jest upodobniona do Boga w naturze intelektualnej".$ „Bóg [...] na ostatnim miejscu stworzył człowieka [...], aby [...] został postawiony jako kres (terminus) wszystkich innych stworzeń [...]"48. Przedstawia to człowieka również jako zwierzę, bo ma w sobie wszystko to, co właściwe zwierzętom.

\section{GODNOŚĆ W FILOZOFII RENESANSU}

Reformacja i inne zmiany społeczne towarzyszące wiekom XVI i XVII przyczyniły się do pewnych modyfikacji w postrzeganiu natury człowieka. Z filozofii wieków średnich zaczerpnięto to, co wywyższało człowieka, pomijając niedoskonałość ludzkiej natury. Wciąż żywe pozostawało pojmowanie godności jako wyznacznika moralnego, lecz coraz częściej postulowano odrzucenie uzależnienia godności od stanu pochodzenia (Homines, mihi crede, non nascuntur, sed finguntur $)^{49}$. Człowiek mógł stać się ziemskim bogiem ${ }^{50}$. Pojawiły się także poglądy głoszące godność nie tylko rozumu ludzkiego (duszy), ale także ciała ${ }^{51}$. Mikołaj Dłuski uznał nawet, że o wyjątkowości człowieka świadczy jego budowa anatomiczna ${ }^{52}$. Coraz częściej człowieka uważano za zwierzę (homo animalis), ale zwierzę szczególne, wyróżniające się wśród innych godnością ${ }^{53}$. Godność zaczęto rozumieć jako wartość pierwotną ${ }^{54}$, choć jej genezą wciąż pozostawał Bóg $^{55}$. Filozofia odrodzenia przeniosła ciężar rozważań na temat istoty gatunku ludzkiego z Boga i jego relacji do świata, na człowieka i jego relacji do Boga i świata. Idealizacja człowieka przyczyniła się do rozważania godności człowieka jako podstawy istnienia jego praw, odchodząc od postrzegania jej jako wyznacznika moralnego. Człowiek był cudem (magnum miraculum est homo) ${ }^{56}$. Takie zachłyśnięcie się ludzkim ciałem i jego doskonałością po ponad dziesięciu wiekach traktowania go jako czegoś niegodnego eksplodowało między innymi

48 Ibidem, s. 54.

49 J.D. Tracy, Erasmus, The Growth of Mind, Genève 1972, s. 122.

50 P. de Mirandola, Oratio de hominis dignitate. Mowa o godności człowieka, przeł. i przypisami opatrzyli Z. Nerczuk, M. Olszewski, Warszawa 2010, s. 16-42.

51 Jan z Trzciany (Arudinensis), De natura ac dignitate hominis, „Textus et studia historiam theologiae in Polonia excultae spectatia" 1974, nr 2, s. 249.

52 M. Dłuski, Mowa o wzniosłości i wspaniałości natury ludzkiej, [w:] 700 lat myśli polskiej. Filozofia i myśl społeczna, red. J. Domański, Warszawa 1978, s. 437.

53 Jan z Trzciany (Arudinensis), op. cit., s. 239-248.

54 T. Guz, O naturze wrodzonej godności człowieka, [w:] Normatywny wymiar godności człowieka, red. W. Lis, A. Balicki, Lublin 2012, s. 19; A. Andrzejuk, Filozoficzne ujęcia godności, [w:] Godność jako wartość i problem edukacyjny, red. I. Jazurkiewicz, A.M. de Tchorzowski, Szczecin 2016, s. 44.

55 F.J. Mazurek, Pojęcie godności czlowieka historia i miejsce w projektach konstytucji III Rzeczypospolitej, „Roczniki Nauk Prawnych” 4, 1996, s. 12.

56 J. Czerkawski, Humanizm i scholastyka: studia z dziejów kultury filozoficznej w Polsce w XVI i XVII wieku, Lublin 1992, s. 40. 
w poglądach Pico de Mirandoli, głoszących, że celem człowieka jest tworzenie siebie, samorealizacja ${ }^{57}$. Człowiek nie jest niczym zdeterminowany. Godność nie uzasadniała więc rozumu ludzkiego (jego wyjaśnieniem wciąż pozostawał Bóg), lecz wolność (co podkreślali też Juan Lusi Vives ${ }^{58}$ oraz Giannozzo Mannetti ${ }^{59}$ ), dzięki której człowiek określa sam siebie ${ }^{60}$. Godność w humanizmie traktowała przede wszystkim o dodatnich cechach człowieka (humanizm pozytywny) ${ }^{61}$, choć nie brakowało oczywiście nurtu pesymistycznego, który głosił całkowitą zwyczajność człowieka ${ }^{62}$. W XVII wieku pojawiły się także koncepcje zakładające endogeniczną genezę godności, między inymi Hugo Groota (Grosjusza) ${ }^{63}$. W koncepcji tej wciąż dominował jednak wartościujący walor pojęcia godności ${ }^{64}$. Thomas Hobbes określił godność jako publiczną wartość człowieka, która jest mu nadana przez wspólnotę, co powszechnie nazywa się „godnością” („The public worth of a man, which is the value set on him by the commonwealth, is that which men commonly call »dignity«") ${ }^{65}$, a wartość tę wspólnota rozumie przez urzędy naczelne, sądowe, publiczne lub przez nazwy i tytuły wprowadzone dla odróżnienia tej wartości (,And this value of him by the commonwealth is understood by offices of command, judicature, public employment, or by names and titles introduced for distinction of such value" ${ }^{66}$. Samą wartość Hobbes rozumiał jako jego cenę zależną od potrzeb i osądów innych („The 'value,' or 'worth,' of a man is, as of all other things, his price [...]"). Aby podkreślić uzależnienie wartości człowieka od oceny społeczeństwa, dodaje: nie sprzedawca, lecz kupujący ustala cenę. Pozwólmy więc człowiekowi, jak wielu czyni, przypisywać sobie najwyższą wartość, ale jego prawdziwa „cena” i tak zostanie oszacowana przez innych (,And, as in other things so in men, not the seller but the buyer determines the price. For let a man, as most men do, rate themselves at the highest value they can, yet their true value is no more than it is esteemed by others") ${ }^{67}$.

57 P. de Mirandola, op. cit., s. 52.

58 J.L. Vives, A Fable on Man, [w:] The Renaissance Philosophy of Man, red. E. Cassirer et al, Chicago 1956, s. 386.

59 G. Mannetti, On the Dignity and Exellence of Man, [w:] Renaissance Humanism: An Anthology of Sources, red. M.L. King, Indianapolis 2014, s. 50.

60 A. Kobyliński, O możliwości zbudowania etyki nihilistycznej. Propozycja Gianniego Vattima, Warszawa 2014, s. 228.

61 P. Bühler, Humain à l'image de Dieu, Genève 1989, s. 114.

62 M. de Montaigne, Próby, t. 2, przeł. T. Żeleński (Boy), Warszawa 1957, s. 145-150.

63 A. Masferrer, Taking Human Dignity More Humanely, [w:] Human Dignity of the Vulnerable in the Age of Rights. Interdisciplinary Perspective, red. A. Masferrer, E. Garcia-Sanchez, Zürich 2016, 230-231.

${ }^{64}$ Ibidem, s. 248.

65 T. Hobbes, Lewiatan, czyli materia, forma i władza państwa kościelnego i świeckiego, przeł. C. Zmanierowski, Warszawa 2018, s. 176.

66 Ibidem, s. 176.

67 Ibidem, s. 176-177. 


\section{GODNOŚĆ W EPOCE OŚWIECENIA I W XIX WIEKU}

Gdy już otrząśnięto się z zachwytu nad człowiekiem jako takim i jego cielesnością, coraz więcej uwagi zaczęto przykładać do ciemnych stron ludzkiej natury. Friedrich Nietzsche uważał, że godność nie jest wrodzoną cechą człowieka, lecz nabywa się ją przez poddaństwo (nie wolność). Godność, jaką większość z nas przyjmuje za podstawę tego, jak powinniśmy traktować innych, jest - sugeruje Nietzsche - tylko wygodnicką fantazją słabych ${ }^{68}$. Choć filozofia Nietzschego nie cieszy się współcześnie popularnością, nie można temu stwierdzeniu odmówić trafności. Przecież prawo ma służyć ochronie słabszych i wyrównywać ich szanse $^{69}$. Co więcej, geneza pojęcia godności jest taka sama jak innych pojęć abstrakcyjnych, których powstanie podyktowane jest właśnie lękiem ${ }^{70}$.

David Hume uważał, że wszystkie wartościujące zjawiska jesteśmy w stanie określić jedynie przez porównanie ${ }^{71}$. Nie mają więc one obiektywnej wartości. Podobnie jest z pojęciem godności rozumianej jako wyznacznik etyczny. Określić, czy ktoś postępuje godnie, możemy tylko wówczas, gdy mamy jakiś punkt odniesienia. $\mathrm{W}$ przeciwnym razie dane zachowanie nie będzie podlegało wartościowaniu.

Najpopularniejszą i najczęściej współcześnie cytowaną osiemnastowieczną teorią godności jest ta autorstwa Immanuela Kanta ${ }^{72}$. Myśliciel z Królewca godność określał jako autonomiczność człowieka w samym sobie. Przejawiała się ona w działaniu wynikającym z wnętrza człowieka, a nie z czynników zewnętrznych. Celem człowieka jest realizacja siebie bez odniesienia do otaczającego świata. Tak więc celem człowieka nie jest dążenie do Boga, szczęścia, zaspokajania potrzeb itp. Takie rozumienie godności przypisuje jednostce niczym nieograniczoną wolność, której barierą ma być jedynie wewnętrzna potrzeba człowieka do kierowania się imperatywem kategorycznym ${ }^{73}$. Kantowska teoria godności łączy więc w da-

68 A. Huddleston, "Consecration to Culture": Nietzsche on Slavery and Human Dignity, „Journal of the History of Philosophy” 2014, nr 1, s. 159-160.

69 A. Sobaczyk, Prawo i czlowiek pracujący - między ochrona godności a równości, [w:] Aksjologiczne podstawy prawa pracy i ubezpieczeń spolecznych. Materiaty z XIX Zjazdu Katedr i Zakładów Prawa Pracy i Ubezpieczeń Społecznych, Poznań 15-17 maja 2013 r., red. M. Skąpski, K. Ślebzak, Poznań 2014, s. 1-2.

70 R. Iwicka, Źródła klasycznej demonologii japońskiej, Kraków 2017, s. 8.

71 D. Hume, On the Dignity or Meanness of Human Nature, [w:] Essays: Moral, Political and Literaryed, red. E.F. Miller, Indianapolis: 1985, s. 80-86; A. Masferrer, op. cit., s. 243-244.

72 D. Schönecker, E.E. Schmid, Kant's Ground-Thesis. On Dignity and Value in the Groundwork, „The Journal of Value Inquiry” 2018, nr 53, s. 81-95; M. Rosen, Dignity. Its History and Meaning, Cambridge 2012, s. 19-31; P. Duchliński, A. Kobyliński, R. Moń, E. Podrez, op. cit., s. 201-212; F.J. Mazurek, Godność..., s. 37-41; M.J. Meyer, Idea godności u Kanta a wspótczesna myśl polityczna, [w:] Godność jako kategoria prawna..., s. 43-55; M. Środa, op. cit., s. 155-156; E. Picker, Godność człowieka a życie ludzkie, Warszawa 2007, s. 158.

73 I. Kant, Uzasadnienie metafizyki moralności, przeł. M. Wartenberg, Kęty 2017, s. 22-54. 
nym pojęciu dwa jego rozumienia: jako własność człowieka oraz jako zdolność do kierowania się imperatywem moralnym ${ }^{74}$.

Godną uwagi jest również koncepcja Arthura Schopenhauera, który negował istotę istnienia pojęcia godności. Jak wskazuje Ebenezer Scrooge dziewiętnastowiecznej filozofii ${ }^{75}$, godność stała się dawnym zwyczajem wszystkich zakłopotanych i pustych moralistów (,the shibboleth of all perplexed and empty-headed moralists" ${ }^{76}$. Niemiecki filozof upatrywał w późniejszym wykorzystaniu tego pojęcia źródeł jego instrumentalizacji i łatwego wprzęgania $\mathrm{w}$ w promocję dowolnych koncepcji:

Owo wyrażenie „godność człowieka”, raz użyte przez Kanta, stało się następnie szablonem dla wszystkich bezmyślnych i bezradnych moralistów, którzy pod owym imponującym wyrażeniem „godność człowieka” starali się ukryć swój brak rzeczywistej lub przynajmniej cokolwiek mówiącej podstawy etyki. Rachowali oni nie bez słuszności, że czytelnikowi miło będzie ujrzeć się przyodzianym w taką godność i że to go zupełnie zadowoli ${ }^{77}$.

\section{WSPÓŁCZESNE UJĘCIA GODNOŚCI}

Współcześnie zaobserwować można dwa główne nurty rozumienia pojęcia godności. Pierwszy z nich traktuje godność jako cel postępowania ${ }^{78}$. Nurt ten wciąż uzasadnia istnienie godności, odwołując się do innych pojęć abstrakcyjnych, głównie koncepcji Boga. Drugi sposób percepcji pojęcia godności nazwać można antropologicznym. Według jego przedstawicieli godność jest podstawą ochrony

74 M.J. Meyer, op. cit., s. 44.

75 M. Rosen, op. cit., s. 1.

76 A. Schopenhauer, On the Basis of Morality, przeł. A.B. Bullock, Indianapolis 1965, s. 100.

77 A. Schopenhauer, O podstawie moralności. Rozprawa konkursowa, przeł. Z. Bassakówna, Kraków 2020, s. 66.

$78 \mathrm{~W}$ dalszej części pominięte zostały popularne w doktrynie kościoła katolickiego koncepcje godności traktujące ją jako wyznacznik moralnego postępowania. Zob. J. Maritain, Pisma filozoficzne, przeł. J. Fenrychowa, Kraków 1988; R. Speaman, Osoby. O różnicy między czymś a kimś, przeł. J. Marecki, Warszawa 2001; M.A. Krąpiec, Człowiek i polityka, Lublin 2007, a także tego samego autora: Ja-człowiek. Zarys antropologii filozoficznej, Lublin 1974 oraz Metafizyka. Zarys podstawowych zagadnień, Lublin 1978; T. Styczeń, W drodze do etyki, Lublin 1984; K. Wojtyła (Jan Paweł II), Centesimus annus, w setnq rocznicę encykliki ,Rerum novarum” z 15 maja 1991 r., [w:] Encykliki Ojca Świętego Jana Pawła II, Kraków 2003, a także tego samego autora: Dives in misericordia. Encyklika o Bożym Miłosierdziu, Poznań 1980 i Evangelium Vitae. Ewangelia życia, Poznań 1995 oraz Laborem exercens, Wrocław 1995; M. Dróżdż, Godność osoby ludzkiej jako fundament i cel komunikacji medialnej, „Studia Socialia Cracoviensia” 2016, nr 2, s. 11-28; W. Chudy, Prawda człowieka i prawda o człowieku, [w:] Człowiek, wartości, sens. Studia z psychologii egzystencji, red. K. Popielski, Lublin 1996, s. 139-141; M. Ossowska, Pojęcie godności, „Etyka” 1996, nr 1; s. 19-29; N. Luhmann, Grundrechte als Institution, Ein Beitrag zur politischen Soziologie, Berlin 1974; C.S. Bartnik, Personalizm, Lublin 1995; H. Piluś, Godność człowieka jako osoby, Warszawa 1998; Ku rozumieniu godności człowieka, red. P. Duchliński, G. Hołub, Kraków 2008; A. Dylus, Godność człowieka: fundament wartości europejskich, „Teologia i Człowiek” 2004, nr 3. 
praw jednostki, w tym przede wszystkim prawa do życia, wolności i równości. Uzasadnienie jej istnienia ma charakter endogeniczny, czyli wynika z samego faktu bycia człowiekiem, a to, co wyróżnia człowieka wśród zwierząt, to jego morfologia ${ }^{79}$. Człowiek w świecie jest niczym innym jak tylko zwierzęciem, czyli wytworem procesu ewolucji. Dlatego wszystkie cechy, które ma, w jakimś stopniu musiały też być $\mathrm{w}$ jego poprzednich stadiach ewolucyjnych ${ }^{80}$. Niektórzy $\mathrm{z}$ tego faktu wyciągają wniosek, że zwierzęta i ludzie mają jednakowe prawa ${ }^{81}$. Część autorów stara się połączyć obie koncepcje (człowieka stworzonego przez Boga imago Dei — i człowieka powstałego w drodze ewolucji - homo naturalis), twierdząc, że całościowo postrzegany człowiek rodzi się wskutek ,podwójnego zapłodnienia", jako taki ma nie tylko rodziców ziemskich i biologicznych, ale i Ojca niebieskiego ${ }^{82}$. Z kolei Francis Fukuyama upatruje źródeł godności w naturze człowieka ${ }^{83}$ jako elementu świata przyrody ${ }^{84}$. Jak twierdzi autor, nie można przypisywać człowieczeństwa istocie tylko ze względu na jakieś poszczególne cechy. Dopiero one wszystkie razem wzięte, choćby nawet były tylko potencjalne ${ }^{85}$, wyróżniają człowieka i pozwalają przypisać mu walor godności ${ }^{86}$.

Dla Jürgena Habermasa ${ }^{87}$ prawa człowieka są formą godności, są niepodzielne, to znaczy zyskują sens dopiero wtedy, gdy istnieją wspólnie z prawami społecznymi i kulturalnymi.

Spośród wielu współczesnych koncepcji pojęcia godności na uznanie zasługuje również ta wypracowana przez Hannah Arendt, z niezrozumiałych względów pomijana w dyskursie. Według autorki godność jest pojęciem czysto politycznym. Podstawą jej istnienia jest zasada pluralizmu (principle of plurality) ${ }^{88}$. Istnienie godności zależy od jej akceptacji przez wspólnotę, w której żyje jej nosiciel ergo godność nie istnieje bez jej potrzeby (assertion) i uznania (recognition) ${ }^{89}$. W Korzeniach totalitaryzmu Arendt wskazywała, że celem państwa totalitarnego

79 E.M. Engels, Biologie und Ethik, Stuttgart 1999, s. 24.

${ }^{80}$ P. Kunzmann, ,Nic jak tylko ssaki?”, [w:] Szkice o godności człowieka, red. M. Piechowiak, T. Turowski, Zielona Góra 2012, s. 196.

81 P. Singer, Wyzwolenie praw zwierząt, przeł. A. Alichniewicz, A. Szczęsna, Warszawa 2018, s. 16-26.

82 Z. Mirek, Godność człowieka w perspektywie biologii, [w:] Godność w perspektywie nauk, red. H. Grzmil-Tylutki, Z Mirek, Kraków 2012, s. 56.

${ }^{83}$ F. Fukuyama, Koniec czlowieka. Konsekwencje rewolucji biotechnologicznej, przeł. B. Pietrzyk, Kraków 2004, s. 18.

84 Ibidem, s. 211.

85 Por. M. Rowlands, Animals like Us, New York 2002, s. 44-60.

86 F. Fukuyama, op. cit., s. 224-226.

87 J. Habermas, Przyszłość natury ludzkiej. Czy zmierzamy do eugeniki liberalnej?, przeł. M. Łukasiewicz, Warszawa 2003, s. 217.

88 J.D. Macready, Hannah Arendt and the Fragility of Human Dignity, Lanham 2018, s. 2.

89 Ibidem, s. 11. 
jest zniszczenie godności rozumiane jako nieuznawanie jej (przez państwo), co w konsekwencji wyklucza potrzebę jej istnienia ${ }^{90}$.

\section{PROPOZYCJA AUTORA}

Godność nie stanowi samoistnego bytu. Jest to konceptualny wytwór człowieka, mający na celu uzasadnienie szczególnej ochrony tego, co uważa się za wymagające tej ochrony ze względu zarówno na interes indywidualny, jak i zbiorowy, Nie można zatem mówić o naruszeniu godności per se. Jest ona naruszana za każdym razem, gdy naruszone zostaje jakiekolwiek dobro człowieka. Stwierdzenie to konstytuuje konieczność istnienia zakazu uznawania godności jako dobra prawnego. Jej szczególny charakter ujęty we współczesnym prawodawstwie czyni ją gwarantem istnienia innych dóbr, nie nadając jej jednak przymiotu wartości, nawet tej najwyższej ${ }^{91}$. Godność jako semiotyczna próba uzasadnienia szczególnej pozycji człowieka nie posiada wartości, ani też tą wartością nie jest. Należy odrzucić zatem ideę jej absolutyzacji ${ }^{92}$, przekonanie o jej najwyższej wartości. Godność jedynie konstytuuje wartość innych dóbr i ich istnienia. Tak jak Bóg w teologii, tak godność w umysłach racjonalnego społeczeństwa pozostaje egzegezą bytu dóbr i wartości. Jest więc pojęciem porządkującym współczesną aksjologię. Tak jak egzegeza pojęcia Boga prowadzi do wypaczenia każdej religii i wiary, tak samo godność jako koncept daje możliwość zdegenerowania wartości. Reasumując, godność jako praprzyczyna innych aksjomatów, sama jednocześnie nim nie będąc, jest naruszana w każdym przypadku naruszenia tych wartości, jednak naruszenie to nigdy nie jest wprost skierowane przeciwko niej (tak jak atak na prezydenta, posła czy inną osobę reprezentującą państwo nie narusza istoty tego ostatniego). Atakując zbrojnie państwo, nie zmierzamy do nihilizacji pojęcia państwa jako konstruktu pojęciowego, a jedynie występujemy przeciwko konkretnemu podmiotowi. Tak samo eksterminując ludzkość, nie zmierzamy do zniszczenia idei człowieka, a tym samym jego godności. Podejmując działania mające w powszechnym uznaniu charakter naruszający godność ludzką, nigdy nie zmierzamy do naruszenia godności jako samej idei, lecz do pogwałcenia wartości przez nią gwarantowanych.

Godność, tak jak pojęcie Boga, wciąż pozostaje jedynie wymysłem lingwistycznym ${ }^{93}$, który ma na celu uzasadnienie wartości utrwalonych w przekonaniu

${ }^{90}$ H. Arendt, Korzenie totalitaryzmu, przeł. M. Szawiel, D. Grinberg, t. 1, Warszawa 2008, s. 142 .

91 Inaczej odczytuje tę kwestię M. Scheler, Der Formalismus in der Ethik und die Materiale Wertethik, Halle, 1916, s. 521.

92 E. Picker, op. cit., s. 5-6; F.J. Mazurek, Godność..., s. 17-18.

93 Jak wskazano na wstępie, pojęcie Boga służyło jedynie uzasadnieniu pewnych zjawisk (Dlaczego występuje zjawisko X? Bo Bóg istnieje itp.). Ponadto należy zauważyć, że pojęcie Boga 
społecznym lub w przekonaniu ustawodawcy. Jest to pojęcie upowszechnione po doświadczeniach drugiej wojny światowej, które, jak się wydaje, miało stanowić kościec ochrony praw jednostki drastycznie pogwałconych w czasie konfliktów zbrojnych. Prawo to nic innego jak powszechne zaakceptowanie ograniczenia wolności jednostek za ich zgodą i poparciem ${ }^{94}$. Na im więcej ograniczeń godzą się jednostki, tym wyższy stopień rozwoju społecznego (przyjmując, że rozważania te odnoszą się do społeczności respektujących zasady demokratycznego państwa prawa). Pojęcie godności ma zatem chronić człowieka przed nadmiernym ograniczeniem jego swobód i uprawnień. Tak więc treścią godności jest z jednej strony odrzucenie możliwości naruszenia praw jednostki dla dobra innej jednostki lub zbiorowości, nawet za jej zgodą, z drugiej — ograniczenie dla pozostałych jednostek, którego nie można przekroczyć. Jest to swoista umowa, treścią której jest ograniczenie wolności jednostki przez zakaz naruszania wolności innych. Wprowadzając godność do dyskursu prawniczego, zgadzamy się na ograniczenie naszej wolności do nienaruszalności wolności innych jednostek, czego uzasadnieniem jest sam fakt bycia przez drugą stronę człowiekiem, przy jednoczesnym respektowaniu tego samego ograniczenia przez inne strony.

Godność traktować należy jako wyjątkową charakterystykę osoby ludzkiej ${ }^{95}$, bez względu na to, jaki przypisujemy jej cel. Właśnie na takiej teleologicznej ideologizacji opierają się spory wokół tego pojęcia. Jak trafnie konstatuje Arendt, godność zależy od jej pozycji w hierarchii życia społecznego ${ }^{96}$. Pamiętać jednak należy, że jest to pojęcie abstrakcyjne uzasadniające inne pojęcia abstrakcyjne. Jego istnienie jest zatem zależne od jego percepcji wśród użytkowników. Równie dobrze można pokusić się o wymyślenie lub użycie innego wyrażenia, dobitniej określającego pozycję człowieka. Na przykład: rex mundi, deus in terra. Czym skończyło się odwieczne wywyższanie człowieka? Danie mu poczucia bezkarności, statusu władcy i właściciela świata? Częściową rację ma Marek Piechowiak, traktując godność jako kategorię pustą, gdy nie jesteśmy w stanie odpowiedzieć na pytanie, na czym polega ludzka wyjątkowość ${ }^{97}$. W rozumowaniu autora zmienić należy warunek z niemożności wskazania owej „wyjątkowości” człowieka w świecie na brak jej akceptacji społecznej. Przy braku wewnętrznej potrzeby przestrzegania normy nie stanie się ona prawem, choćby nim nawet formalnie była. Tak więc godność traktujemy jako założenie teoretyczne istnienia praw jednostki.

zawsze tym pojęciem pozostanie, gdyż potwierdzenie jego istnienia byłoby końcem wiary, a tym samym religii.

94 Pamiętać bowiem należy, że wartość prawa ma charakter konwencjonalny. Oznacza to tyle, że pozostaje ono skutecznym instrumentem ochrony praw jedynie tak długo, jak długo jego użytkownicy akceptują przyjętą konwencję. W przeciwnym wypadku staje się ono zbiorem słów bez znaczenia społecznego, co wielokrotnie pokazała historia (na przykład ludobójstwa w Rwandzie czy Kambodży).

95 P. Duchliński, A. Kobyliński, R. Moń, E. Podrez, op. cit., s. 194.

96 J.D. Macready, op. cit., s. 53-55.

97 M. Piechowiak, Tomasza z Akwinu koncepcja godności..., s. 220-221. 
Jest to klasyczny przykład wyjaśniania zjawisk (tu: istnienia praw i uprawnień człowieka) przez pojęcie abstrakcyjne. Jak się wydaje, jest to oczywiście błędne rozumowanie - człowiek jest człowiekiem, bo ma godność — oparte na absolutyzacji tej ostatniej, lecz godności nie da się w inny sposób przedstawić. Niemniej jednak w naukach humanistycznych nie można całkowicie zrezygnować z wykładni pojęć. Podsumowując, godność jest niczym innym jak specyficzną cechą człowieka, której istnienie powszechnie akceptujemy i której istotą jest uzasadnienie praw i uprawnień, z których korzysta człowiek. Pojęcie to jest tylko niezadowalającą próbą określenia istnienia praw człowieka, która niczym nie różni się od antycznych czy średniowiecznych koncepcji tłumaczących istotę człowieczeństwa. Nomen omen ,godnym” uwagi osiągnięciem jest obiektywizacja pojęcia godności, przynamniej w sferze prawnej. Aby móc mówić o jej istnieniu, należy przyjąć kryteria obiektywne, a wręcz antropologiczne usytuowania człowieka.

$\mathrm{Z}$ faktu godności wynikają prawa i obowiązki. Prawa w zasadzie określić można jako wolność negatywną ${ }^{98}$, czyli wolność od ujemnych postaw ze strony innych, na przykład wolność od strachu, od poniżenia itp. Lustrzanym odbiciem uprawnień wynikających z godności jest katalog ograniczeń naszej wolności, który odpowiada negatywnej wolności innych ludzi. Tak więc godność ma rację bytu jedynie w relacjach międzyludzkich. Hipotetycznie zakładając człowieka żyjącego w świecie bez innych ludzi, pojęcie godności jest zbędne. Co więcej, warunek sine qua non jej istnienia stanowi akceptacja społeczna. A przez tę ostatnią rozumieć należy nic innego jak zdolność limitacji pierwotnie nieograniczonej wolności. Godność poza społeczeństwem nie ma racji bytu. W odniesieniu do zaprezentowanego poglądu skrajnie nieracjonalnym wydaje się wykorzystywanie pojęcia godności do tworzenia tworów językowych takich jak postawy godnościowe ${ }^{99}$ albo postawy szlachetnościowe ${ }^{100}$ rozumiane jako postawy społeczne stawiające sobie za cel obronę indywidualnych przekonań. Widać tu ponownie zakorzenienie rozumienia pojęcia godności jako wartości moralnej. A przecież godność nie jest wartością, lecz cechą człowieka nie odnoszącą się w swojej treści do kanonów etycznych. Nieuzasadnione wydaję się także stanowisko Janusza Mariańskiego, który przedstawia postawę pragmatyczną jako opozycję do postawy godnościowej w sposób mający skrajnie pejoratywny wydźwięk. Nieprawdą jest bowiem, ażeby ludzie, którzy skłonni są ograniczyć swoje prawa, nie szanują własnych ideałów. Postawą niegodną jest tu raczej stwierdzenie, że część społeczeństwa określona przez autora „pragmatystami” godności nie ma ${ }^{101}$. Człowiek nie jest w stanie wyzbyć się godności, choćby nie wiadomo, co robił. Naruszanie godności innych stanowi przejaw braku akceptacji potrzeby jej istnienia. Nie oznacza to jednak,

98 S. Grzybowski, Prawo cywilne. Zarys części ogólnej, Warszawa 1978, s. 32.

99 J. Mariański, op. cit., s. 257.

100 M. Ossowska, Normy moralne. Próba systematyzacji, Warszawa 1970, s. 518; J. Mariański, op. cit., s. 257.

101 J. Mariański, op. cit., s. 261. 
że osoby te owej godności nie mają i mamy postępować tak, jak one. Właściwą reakcją na wszelkie przejawy naruszenia godności wydaje się być prawo karne. Nie zmienia to ostatecznego charakteru tej gałęzi prawa. Prawo karne zawsze jest ultima ratio. Tak więc pojęcie godności jako niesprawdzalne, nad wyraz nieostre i abstrakcyjne w swojej naturze, nie powinno być stosowane w karnistyce. Godność jest przymiotem człowieka, z którego wynikają jego prawa i wolności. Dlatego każdorazowe naruszenie tych praw i wolności zawsze godzi w godność. Nie ma więc sensu wskazywania jej jako przedmiotu ochrony. Także w przypadku przestępstw przeciwko czci nie należy jej wyszczególniać ani jako rodzajowy, ani tym bardziej indywidualny przedmiot ochrony.

\title{
HOW THE DIGNITY WAS UNDERSTOOD IN THE PAST AND HOW IT SHOULD BE TODAY
}

\begin{abstract}
Summary
In the current legal discourse, the concept of dignity is becoming more common. It is considered the highest axiom, whose every violation deserves to be condemned. However, we forget about the conceptual basis of a given concept, its history, and original overtones. We do not remember that certain concepts are created solely to systematize the created or existing social and political situations. The purpose of the article is an attempt to answer the question of how to understand the concept of dignity in legal discourse. It is worth bearing in mind that dignity is indicated as "this" (value or maybe something else) from which human rights originate. That is why it should be rejected as a value because the value itself is not a value. However, one must opt for an objective understanding of dignity, rejecting its moral background proposed, among others by the doctrine of the Catholic Church, if we want to treat it as a legal category.
\end{abstract}

Keywords: dignity, value, legal category

\section{BIBLIOGRAFIA}

Andrzejuk A., Filozoficzne ujęcia godności, [w:] Godność jako wartość i problem edukacyjny, red. I. Jazurkiewicz, A.M. de Tchorzewski, Szczecin 2016.

Arendt H., Korzenie totalitaryzmu, przeł. M. Szawiel, D. Grinberg, t. 1, Warszawa 2008.

Bartnik C.S., Personalizm, Lublin 1995.

Bartsch R., Dynamic Conceptual Semantics. A Logico-Philosophical Investigation into Concept Formation and Understanding, Leyland 1998.

Bosek L., Gwarancje godności ludzkiej i ich wpływ na polskie prawo cywilne, Warszawa 2012.

Brückner A., Stownik etymologiczny języka polskiego, Kraków 1927.

Bühler P., Humain à l'image de Dieu, Genève 1989.

Chudy W., Prawda człowieka i prawda o człowieku, [w:] Człowiek, wartości, sens. Studia z psychologii egzystencji, red. K. Popielski, Lublin 1996.

Cicero M.T. (Cyceron), O inwencji retorycznej/De inventione, przeł. K. Ekies, Warszawa 2013.

Cicero M.T. (Cyceron), O państwie. O prawach. O powinnościach. O cnotach, Warszawa 1960. 
Ciszewski M., Godność człowieka i wzniostość nauki o nim w ujęciu Franciszka Sylwestra z Ferrary, [w:] Zagadnienie godności człowieka, red. J. Czerkawski, Lublin 1994.

Czerkawski J., Humanizm i scholastyka: studia z dziejów kultury filozoficznej w Polsce w XVI i XVII wieku, Lublin 1992.

Dignity, [hasło w:] Online Etymology Dictionary, https:/www.etymonline.com/word/dignity.

Dłuski M., Mowa o wzniosłości i wspaniałości natury ludzkiej, [w:] 700 lat myśli polskiej. Filozofia i myśl społeczna, red. J. Domański, Warszawa 1978.

Domański J., Godność człowieka a zagadnienie jego wolności w filozofii starożytnej, [w:] Zagadnienie godności człowieka, red. J. Czerkawski, Lublin 1994.

Dróżdż M., Godność osoby ludzkiej jako fundament i cel komunikacji medialnej, „Studia Socialia Cracoviensia” 2016, nr 2.

Duchliński P., Kobyliński A., Moń R., Podrez E., Etyka a fenomen życia, Kraków 2017.

Dylus A., Godność człowieka: fundament wartości europejskich, „Teologia i Człowiek” 2004, nr 3.

Engels E.M., Biologie und Ethik, Stuttgart 1999.

Fukuyama F., Koniec człowieka. Konsekwencje rewolucji biotechnologicznej, przeł. B. Pietrzyk, Kraków 2004.

Gigacz M., Filozoficzna identyfikacja godności osoby, [w:] Zagadnienie godności człowieka, red. J. Czerkawski, Lublin 1994.

Gilfillan K., An Aristotelian Conception of Dignity: Magnanimity and the Happy Life of the Philosopher, Fort Worth, TX 2015.

Guz T., O naturze wrodzonej godności człowieka, [w:] Normatywny wymiar godności człowieka, red. W. Lis, A. Balicki, Lublin 2012.

Habermas J., Przyszłość natury ludzkiej. Czy zmierzamy do eugeniki liberalnej?, przeł. M. Łukasiewicz, Warszawa 2003.

Hobbes T., Lewiatan, czyli materia, forma i władza państwa kościelnego i świeckiego, przeł. C. Zmanierowski, Warszawa 2018.

Huddleston A., “Consecration to Culture”: Nietzsche on Slavery and Human Dignity, „Journal of the History of Philosophy" 2014, nr 1.

Hume D., On the Dignity or Meanness of Human Nature, [w:] Essays: Moral, Political and Literaryed, red. E.F. Miller, Indianapolis 1985.

Iwicka R., Źródła klasycznej demonologii japońskiej, Kraków 2017.

Jan z Trzciany (Arudinensis), De natura ac dignitate hominis, „Textus et studia historiam theologiae in Polonia excultae spectatia" 1974, nr 2.

Jendrzejczak M., Idee sprawiedliwości oraz własności w interpretacji Platona i Arystotelesa, „Studia Ekonomiczne. Zeszyty Naukowe Uniwersytetu Ekonomicznego w Katowicach”2015, nr 236.

Kant I., Uzasadnienie metafizyki moralności, przeł. M. Wartenberg, Kęty 2017.

Kobyliński A., O możliwości zbudowania etyki nihilistycznej. Propozycja Gianniego Vattima, Warszawa 2014.

Korolec J.B., Perfekcjonizm kultury średniowiecznej, [w:] Zagadnienie godności człowieka, red. J. Czerkawski, Lublin 1994.

Krąpiec M.A., Człowiek bytem osobowym. Św. Tomasza koncepcja człowieka, [w:] O godność osoby ludzkiej. Materiały Ogólnopolskiej Konferencji Naukowej zorganizowanej przez Stowarzyszenie SPES VITAE, Radom 22-23 marca 2002 r., red. L.J. Kułakowski, U. Antolak-Kułakowska, Radom 2002.

Krąpiec M.A., Człowiek i polityka, Lublin 2007.

Krąpiec M.A., Ja-człowiek. Zarys antropologii filozoficznej, Lublin 1974

Krąpiec M.A., Metafizyka. Zarys podstawowych zagadnień, Lublin 1978.

Krokiewicz A., Sokrates. Etyka Demokryta i hedonizm Arystypa, Warszawa 2000.

Ku rozumieniu godności człowieka, red. P. Duchliński, G. Hołub, Kraków 2008. 
Kunzmann P., ,,Nic jak tylko ssaki?”, [w:] Szkice o godności człowieka, red. M. Piechowiak, T. Turowski, Zielona Góra 2012.

Luhmann N., Grundrechte als Institution, Ein Beitrag zur politischen Soziologie, Berlin 1974.

Meyer M.J., Idea godności u Kanta a wspótczesna myśl polityczna, [w:] Godność jako kategoria prawna, red. K. Complak, Wrocław 2001.

Macready J.D., Hannah Arendt and the Fragility of Human Dignity, Lanham 2018.

Mannetti G., On the Dignity and Exellence of Man, [w:] Renaissance Humanism: An Anthology of Sources, red. M.L. King, Indianapolis 2014.

Mariański J., Godność ludzka jako wartość społeczno-moralna: mit czy rzeczywistość? Studium interdyscyplinarne, Torun 2016.

Maritain J., Pisma filozoficzne, przeł. J. Fenrychowa, Kraków 1988.

Maryniarczyk A., Dekalog a prawo naturalne, „Człowiek w kulturze. Pismo poświęcone filozofii i kulturze" 1994, nr 3.

Masferrer A., Taking Human Dignity More Humanely, [w:] Human Dignity of the Vulnerable in the Age of Rights. Interdisciplinary Perspective, red. A. Masferrer, E. Garcia-Sanchez, Zürich 2016.

Mazurek F.J., Godność osoby ludzkiej podstawa praw człowieka, Lublin 2001.

Mazurek F.J., Pojęcie godności człowieka historia i miejsce w projektach konstytucji III Rzeczypospolitej, „Roczniki Nauk Prawnych” 4, 1996.

Mirandola P. de, Oratio de hominis dignitate. Mowa o godności człowieka, przeł. i przypisami opatrzyli Z. Nerczuk, M. Olszewski, Warszawa 2010.

Mirek Z., Godność czlowieka w perspektywie biologii, [w:] Godność w perspektywie nauk. Praca zbiorowa, red. H. Grzmil-Tylutki, Z. Mirek, Kraków 2012.

Montaigne M. de, Próby, t. 2, przeł. T. Żeleński (Boy), Warszawa 1957.

Na krawędzi epoki. Rozwój duchowy i działania człowieka, red. J. Rudniański, K. Murawski, Warszawa 1985.

North D., Institutions, Institutional Change and Economic Perfomance, New York 1990.

Ossowska M., Normy moralne. Próba systematyzacji, Warszawa 1970.

Ossowska M., Pojęcie godności, „Etyka” 1966, nr 1.

Pickaers S., La dignité de l'homme selon Saint Thomas d'Aquin, [w:] De dignitate hominis, red. A. Holdeeregger, R. Imbach, R. Suárez de Miguel, Freibourg 1987.

Picker E., Godność człowieka a życie ludzkie. Rozbrat dwóch fundamentalnych wartości jako wyraz narastajacej relatywizacji czlowieka, przeł. J. Merecki, Warszawa 2007.

Piechowiak M., Plato and the Universality of Dignity, „Themis Polska Nova” 2015, nr 2.

Piechowiak M., Tomasza z Akwinu koncepcja godności osoby ludzkiej jako podstawy prawa. Komentarz do rozdziałów 111-113 księgi III Tomasza z Akwinu. Summa contra gentiles, „Poznańskie Studia Teologiczne" 2013, nr 14.

Piluś H., Godność człowieka jako osoby, Warszawa 1998.

Platon, Kratylos, przeł. W. Stefański, Wrocław 1990.

Plutarch, Moralia (wybór), t. 1-2, przeł. Z. Abramowiczówna, Warszawa 1977.

Plutarch, Moralia: wybór pism filozoficzno-popularnych, przeł. i oprac. Z. Abramowiczówna, Wrocław 1954.

Rosen M., Dignity. Its History and Meaning, Cambridge 2012.

Rowlands M., Animals Like Us, New York 2002.

Scheler M., Der Formalismus in der Ethik und die Materiale Wertethik, Halle 1916.

Schönecker D., Schmid E.E., Kant's Ground-Thesis. On Dignity and Value in the Groundwork, „The Journal of Value Inquiry” 2018, nr 53.

Schopenhauer A., O podstawie moralności. Rozprawa konkursowa, przeł. Z. Bassakówna, Kraków 2020.

Schopenhauer A., On the Basis of Morality, przeł. A.B. Bullock, Indianapolis 1965. 
Seneca Lucius Annaeus (Seneka), Listy moralne do Lucyliusza, przeł. W. Kornatowski, Warszawa 2010.

Singer P., Wyzwolenie praw zwierzą, przeł. A. Alichniewicz, A. Szczęsna, Warszawa 2018.

Sobaczyk A., Prawo i człowiek pracujący - międzyochrona godności a równości, [w:] Aksjologiczne podstawy prawa pracy i ubezpieczeń społecznych. Materiaty z XIX Zjazdu Katedr i Zaktadów Prawa Pracy i Ubezpieczeń Społecznych, Poznań 15-17 maja 2013 r., red. M. Skąpski, K. Ślebzak, Poznań 2014.

Soto Kloss E., Starotestamentowe podstawy godności człowieka, [w:] Godność jako kategoria prawna (opracowania i materiały), red. K. Complak, Wrocław 2001.

Speaman R., Osoby. O różnicy między czymś a kimś, przeł. J. Marecki, Warszawa 2001.

Steenberghen F. van, R. Guindon: Béatitude de théologie morale chez Saint Thomas d'Aquin-Iterpretation, „Revue Philosophique de Louvain” 1959, nr 55.

Styczeń T., $W$ drodze do etyki, Lublin 1984.

Swieżawski S., Dzieje filozofii europejskiej w XV wieku, t. 6. Człowiek, Warszawa 1983.

Środa M., Idea godności w kulturze i etyce, Warszawa 1993.

Św. Augustyn, Wyznania, przeł. Z. Kubiak, Kraków 2018.

Tatarkiewicz W., Historia filozofii, t. 2, Warszawa 1988.

Tracy J.D., Erasmus, The Growth of a Mind, Genève 1972.

Verdoss A., Statisches und dynamisches Naturrecht, Fryburg 1971.

Vives J.L., A Fable on Man, [w:] The Renaissance Philosophy of Man, red. E. Cassirer et al., Chicago 1956.

Wojtyła K. (Jan Paweł II), Centesimus annus, w setna rocznicę encykliki ,, Rerum novarum” z 15 maja 1991 r., [w:] Encykliki Ojca Świętego Jana Pawła II, Kraków 2003.

Wojtyła K. (Jan Paweł II), Dives in misericordia. Encyklika o Bożym Miłosierdziu, Poznań 1980.

Wojtyła K. (Jan Paweł II), Evangelium Vitae. Ewangelia życia, Poznań 1995.

Wojtyła K. (Jan Paweł II), Laborem exercens, Wrocław 1995.

Woznicki A.N., Dignity of Man as a Person. Essays on the Christian Humanism of His Holiness John Paul II, San Francisco 1987.

Xenophon, Memorabilia, Ithaca-London 1994. 